\title{
The Development of Organizational and Managerial Skills of Future Technology and Entrepreneurship Teachers during Professional Training
}

\author{
Artem Edikovich Islamov ${ }^{1}$ \\ ${ }^{1}$ Kazan Federal University, Russia \\ Correspondence: Artem Edikovich Islamov, Kazan Federal University, Kazanskaya street, 89, Yelabuga, 423600, \\ Russia. E-mail: dimban@rambler.ru
}

Received: September 23, 2014 Accepted: November 17, 2014 Online Published: December 2, 2014

doi:10.5539/ass.v11n1p354

URL: http://dx.doi.org/10.5539/ass.v11n1p354

\begin{abstract}
The article aims to elaborate certain patterns of formation of organizational and managerial expertise of future teachers of technology and entrepreneurship. The main study approaches were integrative, expertise and activity approaches defining methodology, content and technology of forming organizational and managerial expertise of future teachers. The presented pattern of organizational and managerial expertise of future technology and entrepreneurship teachers includes the following sections: regulatory and target, theoretical and methodological, algorithmic, procedural and productive-evaluative sections. This article material can be useful for high school professors who offer specific training for future technology and entrepreneurship teachers, for teachers and school managers within specific training courses and when enhancing professional skills of technology and entrepreneurship teachers.
\end{abstract}

Keywords: professional education, organizational and managerial expertise, future technology and entrepreneurship teacher, pattern

\section{Introduction}

The need to obtain basics in technology education is an emerging trend, existing as a response to challenges of social development, creative and organizational development of individual, offering professional and everyday life skills as well as willingness to act according to market conditions while preserving national crafts and traditions. In the domestic secondary education system, the subject discipline "Technology" covers all stages of education starting from first up to 11 th grade. It performs several functions: adaptation, self-determination, implementation of gifts and skills of student based on acquired knowledge and types of activities, which correspond to the targets of student's participation in social and non-professional work, as well as forms their mindset, values and ideals (Lerner, 1999).

The tasks set to form preparedness of students for everyday life, social and professional activities within educational course "Technology" largely depend on the degree of readiness of future technology and entrepreneurship teachers in higher professional education, which in turn integrates three areas: pedagogical, technological and entrepreneurial areas meeting requirements of State Educational Standards (Hamitov, 2007; Skachkova, 2012; Lacko, 2009). The link of pedagogy with technical sciences, natural sciences and socio-economic sciences lies in the basis of professional training of future technology and entrepreneurship teachers. The article's author notes (Pavlova, 2013), "Typical peculiarity of professional and pedagogical work of technology teacher is that it includes the arrangement and management of students' practical activities in form of productive labor", meaning that teacher's training activity is fully integrated into managing activities for work and training.

In every stage of educational process within "Technology" educational course teacher has to implement his organizational and managerial functions including:

- planning of work and training processes (selection of study material, work instruments, production technologies and teaching methods);

- taking into account cognitive abilities and creativity of students;

- arranging and managing practical activities of students; 
- elaborating control and evaluation methods in order to monitor the study process;

- managing educational course and, if necessary, its updating and correction;

- guiding students' study activities during work and training;

- Monitoring the outcomes of study process.

However, there is not enough attention paid to acquiring knowledge and experience for organizational and managerial skills during training course, which in its turn appears as an integral part of professional expertise for future technology and entrepreneurship teachers. This aspect has identified the need to build and maintain organizational and managerial expertise of future technology and entrepreneurship teachers.

\section{Results}

The theoretical base for organizational and managerial competences creation for future technology and entrepreneurship teachers are: integrative, competence and activity approaches that ensure optimal conditions arrangement and integrity of science and practice defining procedures and limits of this research.

Integrative approach (Zimnya \& Zemtsova, 2008; Chapaev \& Akimova, 2012) implementation is closely interrelated with the need to integrate various disciplines: pedagogy, psychology, labor management, industrial engineering etc.; to integrate and adapt ideas and concepts to educational realities; to integrate ways and means of education. All this is aimed to create organizational and managerial expertise of future technology and entrepreneurship teachers on the general scientific level.

Competence-based approach (Masalimova \& Shaidullina, 2006; Baydenko, 2005; Ibragimov, 2007) defines certain grounds of modern Russian professional education and forms the basis for educational standards implementation. The requirements for modern schoolteacher within the framework of competence patterns have changed significantly: the teacher is a person who possesses techniques for pedagogical activity, fosters students' creativity and personal development skills in particular subject area. This competence approach and personal development needs of future technology and entrepreneurship teachers will require substantial changes in training management, its content, assessment and educational technologies implementation.

Organizational and managerial skills development should take place during activities based on development of personal qualities of future technology and entrepreneurship teachers. This fact ensures activity-based approach for pedagogical process itself. Learning by doing and independent development of problem solving skills through experience forms the basis of modern active learning practice that contributes to acquiring of person's necessary competencies (Dewey, 2000; Lazarev, 2000).

Shaping model in order to form organizational and managerial competences, the author used principles that cannot be underestimated within professional training of future technology and entrepreneurship teachers. These are:

- integrity principle which provides a complete holistic view about professional training, the subject area, pedagogical processes of organizational and management training;

- principle of theory and practice unity which ensures best conditions for forming organizational and managerial competences through perception and practical experience gaining, approval and development of theoretical knowledge;

- predictability principle that influences conformity and development of consistent and educational experience based on the analysis of pedagogical situations;

- adaptation principle which develops the ability of future teacher to socialize within his profession under those conditions that he has created for work and training process of his students;

- principle of professional and personal development defining the base for the formation of motivation and willingness for self-development of future technology and entrepreneurship teachers;

- Principle of introspection, which ensures the self-esteem of every action of a teacher during his professional activity, which in turn leads to the development of thinking, the adjustment of educational process and to the achievement of specific goals.

Pedagogical modeling represents the ability to combine theoretical and practical concepts of the subject area, to define blocks, stages, structure and hierarchy of organizational and managerial skills development of future technology and entrepreneurship teachers. Author's elaborated model (Figure 1) includes the following chart structure: regulative-target block, theoretical and methodological block, algorithmic, process, result-evaluative blocks. Target-regulative framework in the field of professional education defines the regulative-target block structure: Federal Education Act, Federal Targeted Program for Education Development for 2011-2015, State 
Educational Standard for training areas. Social order represents certain objective requirements for professional education outcomes based on State educational policy implementation, on the requirements of future employers, market economy conditions and society.

Theoretical and methodological blocks of represented chart includes the reasoning of aggregated approaches (integrative, competence and activity approaches) and principles (integrity, combination of theory and practice, predictability, adaptation, professional and personal development, introspection principles). Let us define the aims of organizational and managerial skills development for future technology and entrepreneurship teachers: -formation and expansion of organization and managerial theoretical framework in field of educational organization and management; facility and labor management; development of skills and competences in planning, in decision-making skills implemented in various work situations, forecasting activities and analysis in management and organization of students' educational process within "Technology" subject area; development of motivation and eagerness for self-development for future teachers in specific profession; formation of future teachers' experience in field of organization and management of students' educational activities.

Algorithmic block of the represented chart includes stages of forming the organizational and managerial competences of future technology and entrepreneurship teachers:

- Defining structure and content of organizational and managerial competence;

- designing structure and content of organizational and management training;

- elaborating curriculum and study materials in order to ensure organizational and managerial training;

- Verification of organizational and managerial competence enhancement.

These stages are consequently implemented during organizational and managerial training of future technology and entrepreneurship teachers throughout active and interactive teaching methods, through integration with artificial professional environment, passing internship and drawing graduate work.

Procedural block of represented chart defines specific ways for developing organizational and managerial skills of future technology and entrepreneurship teachers as a whole as well as for its components. Each of components of organizational and managerial skills (cognitive, planning and predictive, functional and verification skills) determine characteristics level of future teacher personality, his abilities for professional work in the field of organization and management of pedagogical activity, willingness to work and taking the responsibility.

Professional training serves as a basis for organizational and managerial skills development. We propose to introduce educational module "basics of organizational and managerial work of technology and entrepreneurship teacher" as a variable part of professional training. The structure of discipline includes theoretical and practical workshops as well as independent work. Development of organizational and managerial competence is carried out both during teaching and studying course, and preparing graduate work. Development of organizational and managerial competence occurs through playing (business games) and real-life situations (interactive and problem-solving lectures, case and problem-solving tasks, study simulations, project methods).

The chart uses the following abbreviations: OMSD - organizational and managerial skills development; OMS organizational and managerial skills; OMT - organizational and management training; T\&E- technology and entrepreneurship; TMS - training and methodological support.

Result-evaluative block serves to define the level of organizational and managerial skills development of future technology and entrepreneurship teachers by totaling score of its components (cognitive, planning and forecasting, functional, introspective components) expressed in one of the development levels:

- critical (poor skills and thinking in the field of organizational and managerial activity),

- adaptive (actions based on stereotypes, unstable organizational and managerial activity),

- base (the teacher is able to organize and manage activities and working process),

- Leadership (the teacher provides high standards of operation, is able to solve problems at teaching staff level).

Thus, the elaborated model of organizational and managerial competence of future technology and entrepreneurship teachers is presented as a way to arrange organizational and management training process through the set of goals, objectives, approaches, principles, processes, pedagogical methods and instruments, and valuation system.

Figure1. Model of organizational and managerial skills development of future technology and entrepreneurship teacher 


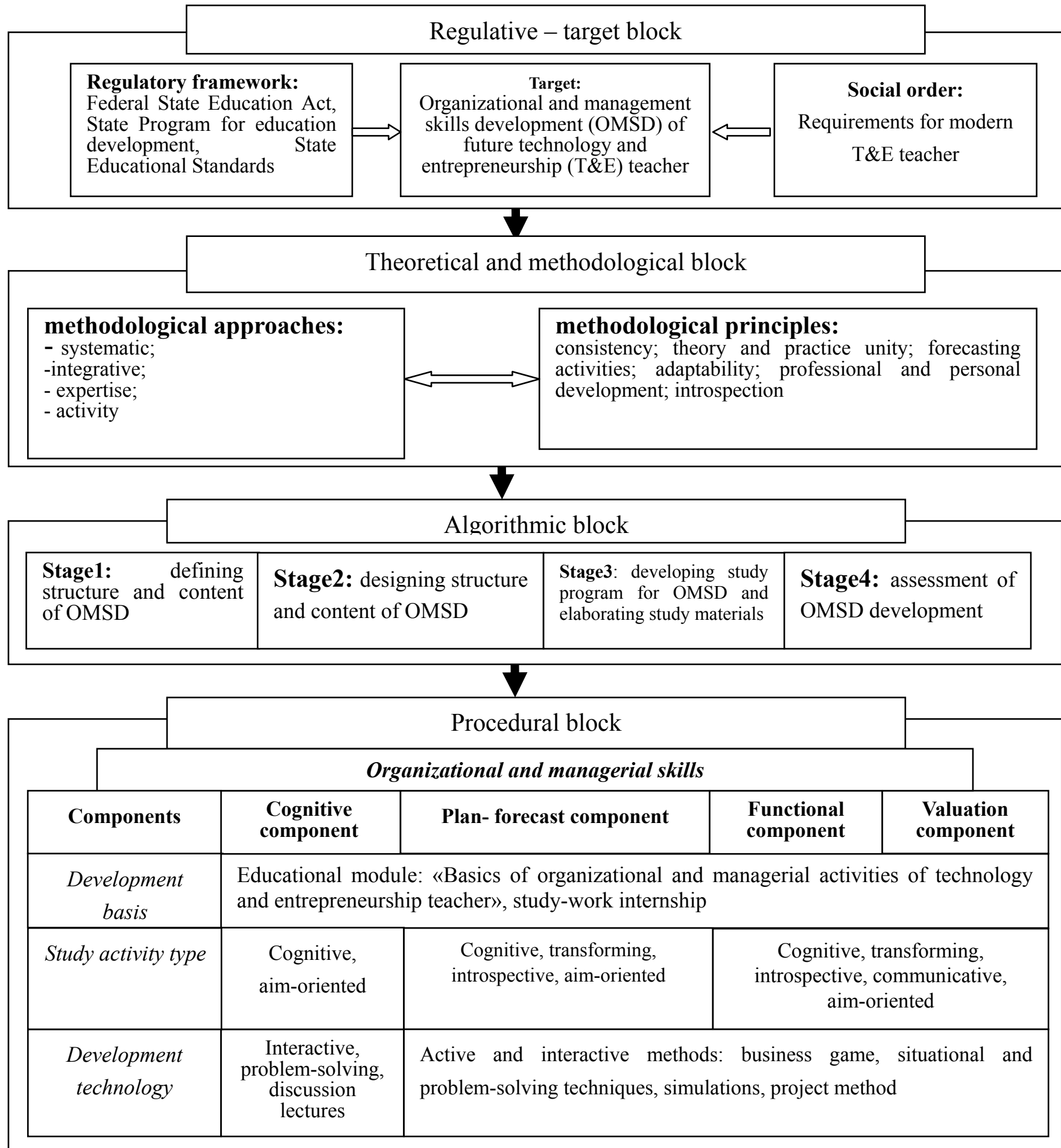

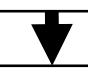

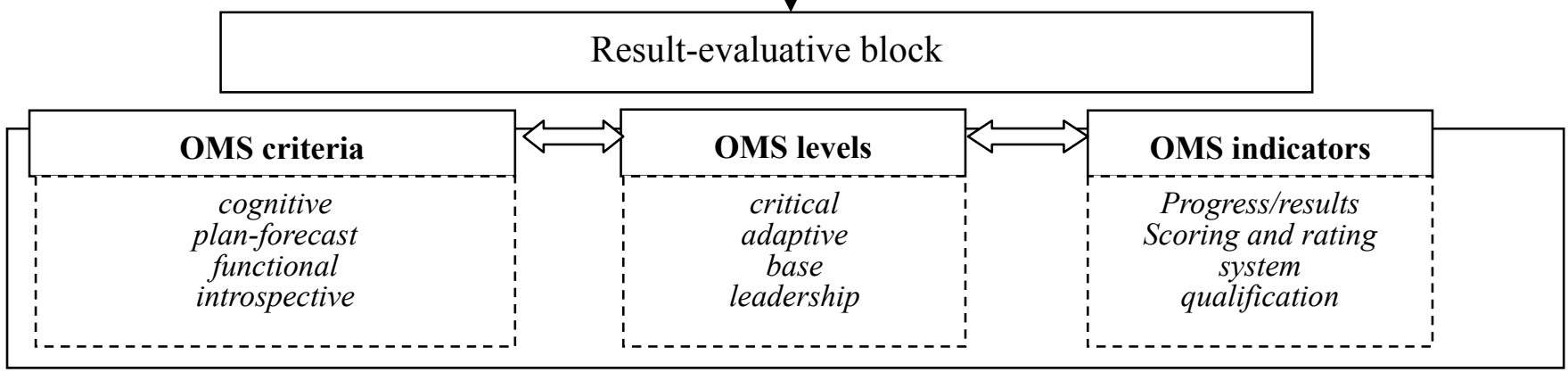




\section{Conclusion}

Thus, the author has elaborated the model of organizational and managerial skills development for future technology and entrepreneurship teachers, which accomplishes several functions:

- normative function complying with training standards and social needs;

- descriptive function that provides structure and links with organizational and management training;

- analytical function as an analysis of actual and planned actions with modeled parameters of specific pattern;

- operational function, providing model's capacities and adjustments making process which allows to aggregate forecast data on the effects on the model;

- Resultant function allowing to apply model to real life conditions of professional training of future technology and entrepreneurship teacher.

The main advantage of elaborated model is that it features a set of structured and integrated information that appropriately reflects real life situations and strengthens possibilities of pedagogical achievement implementing educational and organizational management skills of future technology and entrepreneurship teachers.

\section{Rreferences}

Baydenko, V. I. (2005). Competence-based approach to the design of the state educational standards of higher education. Moscow: Research Center of the quality of training.

Chapaev, N. K., \& Akimova O. B. (2012). Integrative approach to creating akmeologicheskoj oriented system obshchepedagogicheskoj preparation of the teacher of vocational education. Journal of Scientific Dialogue (Pedagogy), 10, 8-18.

Dewey, J. (2000). Democracy and Education. Moscow: Pedagogy.

Hamitov, I. S. (2007). The examination of formed elements of the technological culture of the students of secondary schools. Journal of Science and school, 1, 51-52.

Ibragimov, G. I. (2007). Competence approach in vocational education. Journal of Education Technology \& Society, 10, 377-379.

Lacko, N. A. (2009). Philosophical and psychological foundations of economic competence of future teachers of technology as a factor 'of their professional self-development. Herald of the Chelyabinsk State Pedagogical University, 4, 76-86.

Lazarev, V. S. (2000). Activity-based approach to a new understanding of the goals of higher education. Journal of Pedagogy, 3, 27-34.

Lerner, I. J. (1999). The content of education. Russian Pedagogical Encyclopedia, 2 t. Moscow: Science.

Masalimova, A. R., \& Shaidullina A. R. (2006). Prospects for the use of foreign experience training engineers in the Russian system of vocational education. Problems of energetic, 5-6, 85-92.

Pavlova, L. N. (2013). Managerial competence of the teacher. Journal of Vocational Education, 2, 32-34.

Skachkova, N. V. (2012). Informational aspects of the formation of professional competence of future teachers of technology. European Social Science Journal, 10, 94-102.

Zimnya, I. A., \& Zemtsova E. V. (2008). Integrative approach to the assessment of a single social and professional competence of graduates. Journal of Higher Education Today, 5, 14-19.

\section{Copyrights}

Copyright for this article is retained by the author(s), with first publication rights granted to the journal.

This is an open-access article distributed under the terms and conditions of the Creative Commons Attribution license (http://creativecommons.org/licenses/by/3.0/). 